\title{
Sodium butyrate and peppermint essential oil in jundiá diet: performance, histology, and challenge of Ichthyophthirius multifiliis
}

\author{
Diogo Bessa Neves Spanghero ${ }^{1^{*}, 2}$ (i) Emília Carolina Alencar de Medeiros Spanghero ${ }^{2}$ (i)

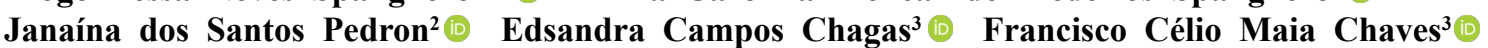 \\ Evoy Zaniboni-Filho ${ }^{2}$ (D)
}

${ }^{1}$ Universidade Federal de Alagoas (UFAL), Laboratório de Inovação em Aquicultura (IN-AQUA), 57200-00, Penedo, AL, Brasil. E-mail: diogospanghero@penedo.ufal.br. "Corresponding author.

${ }^{2}$ Universidade Federal de Santa Catarina (UFSC), Laboratório de Biologia e Cultivo de Peixes de Água Doce (LAPAD), Florianópolis, SC, Brasil. ${ }^{3}$ Embrapa Amazônia Ocidental, Manaus, AM, Brasil.

ABSTRACT: The aim of the present study was to evaluate the zootechnical performance, intestinal mucosa, and reaction to infestation by the parasite Ichthyophthirius multifiliis in jundiá Rhamdia quelen larvae supplemented with Mentha piperita essential oil or sodium butyrate in their diets. Five diets were used over 30 days: diet free of additive inclusion, $0 \%$ (control); inclusion of $1 \%$ or $2 \%$ of $M$. piperita essential oil: $E O 1 \%$ and EO2\%, respectively; and inclusion of $0.25 \%$ or $0.50 \%$ of sodium butyrate: $S B 0.25 \%$ and SBO.50\%, respectively. The different diets were not able to inhibit I. multifiliis infestation. Supplementation with SB0.50\% in their diets presented better performance in all zootechnical parameters analyzed, including a 54\% increase in final weight and $70 \%$ in survival, and increased $(P<0.05)$ both the villi width and the amount of goblet cells present in the intestinal mucosa by approximately $50 \%$. In view of these results, dietary supplementation of $R$. quelen larvae with $0.50 \%$ sodium butyrate for 30 days is recommended.

Key words: organic acids, vegetable extract, larviculture; ichthyophthiriasis, Rhamdia quelen.

Butirato de sódio e óleo essencial de hortelã-pimenta na dieta de jundiá: desempenho, histologia e desafio ao Ichthyophthirius multifiliis

RESUMO: O objetivo do presente estudo foi avaliar o desempenho zootécnico, a mucosa intestinal, a resistência ao estresse e a reação à infestação pelo parasita Ichthyophthirius multifiliis em larvas de jundiá Rhamdia quelen suplementadas com óleo essencial de Mentha piperita ou butirato de sódio em suas dietas. Foram utilizadas cinco dietas por 30 dias: dieta livre de inclusão de aditivos, $0 \%$ (controle); inclusão de $1 \%$ ou $2 \%$ de óleo essencial de M. piperita, EO1\% e EO2\%, respectivamente; e inclusão de 0,25\% ou 0,50\% de butirato de sódio, SB0.25\% e SB $0.50 \%$, respectivamente. As diferentes dietas não foram capazes de inibir a infestação por I. multifiliis. A suplementação com SB0.50\% em suas dietas apresentou melhor desempenho em todos os parâmetros zootécnicos analisados, incluindo um aumento do peso final em $54 \%$ e a sobrevivência em $70 \%$, e aumentou $(P<0,05)$ a largura das vilosidades e a quantidade de células caliciformes presentes na mucosa intestinal em aproximadamente $50 \%$. Em vista desses resultados, recomenda-se a suplementação dietética de larvas de R. quelen com butirato de sódio a $0,50 \%$ por 30 dias.

Palavras-chave: ácidos orgânicos, extrato vegetal, larvicultura; ictiofitiríase, Rhamdia quelen.

\section{INTRODUCTION}

Herbal medicines and organic acids have great potential for use in aquaculture. They are biodegradable and have antimicrobial activities against various bacteria, parasites and fungi (ADEL et al., 2015; AHMED \& SADEK, 2015; KOH et al., 2016; VALLADÃO et al., 2016). Moreover, they are a preventive alternative for maintaining the health of cultured fish, acting in the intestinal tract inhibit the growth pathogenic of bacteria, specially of Gramnegative bacteria, and improving fish digestibility and nutrient absorption, what may benefit zootechnical performance (ZHENG, 2009; TALPUR, 2014; ADEL et al., 2015).

Among the plant species, some authors have reported promising results with the inclusion of Mentha piperita in fish feed. ADEL et al. (2015) 
observed that the addition of $M$. piperita essential oil (EO) to the diet Rutilus frisii kutum promoted higher growth and better feed conversion, in addition to improving the main hematological and immunological parameters of caspian white Rutilus frisii kutum. Other authors have observed the development of anthelmintic activity from the addition of $M$. piperita $\mathrm{EO}$ in pirarucu Arapaima gigas against monogenean Dawestrema spp. (MALHEIROS et al., 2016); a reduction of $70 \%$ in the prevalence of monogenean in Nile tilapia Oreochromis niloticus (HASHIMOTO et al., 2016); and also a cytotoxic effect against Ichthyophthirius multifiliis in an in vitro study (VALLADÃO et al., 2016).

Among organic salts, sodium butyrate has received great attention due to the improvement in growth performance and intestinal function through the addition to the diets of some species of fish, such as Sparus aurata (ROBLES et al., 2013); Nile tilapia Oreochromis niloticus (AHMED \& SADEK 2015), Carassius auratus (SUN et al., 2013), grass carp Ctenopharyngodon idellus (LIU et al, 2016) and the common carp Cyprinus carpio (LIU et al., 2014). In addition, the use of sodium butyrate as an alternative to antibiotics is a target of growing interest in studies carried out in the area of aquaculture (LÜCKSTÄDT, 2008). Other positive effects are also seen in the intestinal tract of several animals (GUILLOTEAU et al., 2010), including enhancement of gut development, control of enteric pathogens, reduction of inflammation, improvement of growth performance (including carcass composition), and modulation of gut microbiota (BEDFORD \& GONG, 2017). In addition to providing energy to the epithelial cells, sodium butyrate was also reported increasing the proliferation and differentiation of the epithelial cells and also improving the barrier function of the colon (ROBLES et al., 2013).

Among the fish species with great potential for continental aquaculture in southern Brazil, the jundiá Rhamdia quelen is the main native species produced (BALDISSEROTTO, 2009). Its production potential has been attributed to the fact that this species exhibits a docile behavior in captivity and apparently a low level of stress when submitted to conventional management methods (ZANIBONI-FILHO \& SCHULZ, 2003), its large size (ZANIBONI-FILHO et al., 2004), and its satisfactory growth even at low temperatures (FRACALOSSI et al., 2004). In this context, this study evaluated the zootechnical performance, intestinal mucosa morphology, and reaction to challenge by the parasite I. multifiliis in jundiá $R$. quelen larvae fed diets supplemented with M. piperita $\mathrm{EO}$ or sodium butyrate.

\section{MATERIALS AND METHODS}

The present study was conducted at the Laboratory of Biology and Cultivation of Freshwater Fish at the Federal University of Santa Catarina (UFSC), according to the procedure approved by the Committee on Ethics in the Use of Animals at UFSC, protocol No. 3451200917. The total of 900 larvae (2.9 $\pm 0.5 \mathrm{mg}$ and $7.9 \pm 1.3 \mathrm{~mm}$ ) were randomly distributed in 15 experimental units (EUs), containing $20 \mathrm{~L}$ of water (60 larvae per EU). Fish were maintained in a water recirculation system coupled with a biological filter, salinized water $\left(2.4 \mathrm{~g} \mathrm{~L}^{-1}-\right.$ sea salt without iodine), 12-h photoperiod, with constant renewal and aeration, for 30 days.

Five extruded diets were used in three replicates: diet free of additive inclusion, $0 \%$ (control); inclusion of $1 \%$ or $2 \%$ of $M$. piperita $\mathrm{EO} 1 \%$ and $\mathrm{EO} 2 \%$, respectively; and inclusion of $0.25 \%$ or $0.50 \%$ sodium butyrate (Sodium butyrate $99 \%$, Sigma-Aldrich, St. Louis, Missouri, USA), SB0.25\% and SB0.50\%, respectively.

\section{Mentha piperita essential oil}

The peppermint essential oil was obtained from the laboratory of medicinal plants and phytochemistry of Embrapa Amazônia Ocidental, located in Manaus (AM, Brazil). Peppermint specimens were grown at the medicinal plant collection also of Embrapa Amazônia Ocidental. Plant shoot (leaves) was removed for essential oil extraction by hydrodistillation in a Clevenger apparatus for 2 hours. In each distillation, $500 \mathrm{~g}$ leaves were used. The essential oil was stored at $4{ }^{\circ} \mathrm{C}$ until analyses (POTZERNHEIM et al., 2012).

The chemical analysis of the essential oil was conducted using gas chromatography with mass spectrometry, according to MORAIS et al. (2012). The main components reported were: $27.5 \%$ menthol, $22.5 \%$ menthofuran, $12.8 \%$ pulegone, $12.5 \%$ menthyl acetate, $11 \%$ menthone, $3.5 \%$ limonene, and 2.1\% 1.8-cineole.

\section{Preparation of diets}

The proximate analysis of the diets included moisture, crude protein, fat, ashes, crude fiber, protein, and which were analyzed by the fish nutrition laboratory of the Federal University of Santa Catarina (LabNutri/UFSC), following standard procedures of the Association of Official Analytical Chemists (Association of Official Analytical Chemists (AOAC), 1999) (Table 1). Carbohydrate analyzes were performed using the RDC method, no. 360 (ANVISA, 2003). 
Table 1 - Ingredients and proximate composition analysis of the experimental diets $\left(\mathrm{g} \mathrm{kg}^{-1}\right)$ supplemented or not with sodium butyrate or peppermint essential oil, which were provided to $R$. quelen for 30 days.

\begin{tabular}{|c|c|c|c|c|c|}
\hline Ingredients $(\%)$ & Control & $\mathrm{EO} 1 \%$ & $\mathrm{EO} 2 \%$ & $\mathrm{SB} 0.25 \%$ & SB $0.50 \%$ \\
\hline Flour residue of salmon $(71 \% \mathrm{CP})$ & 56.00 & 56.00 & 56.00 & 56.00 & 56.00 \\
\hline Corn & 36.00 & 36.00 & 36.00 & 36.00 & 36.00 \\
\hline Soy oil & 4.00 & 4.00 & 4.00 & 4.00 & 4.00 \\
\hline Premix micromineral $^{1}$ & 1.00 & 1.00 & 1.00 & 1.00 & 1.00 \\
\hline Premix macromineral $^{2}$ & 1.00 & 1.00 & 1.00 & 1.00 & 1.00 \\
\hline Cellulose & 2.00 & 2.00 & 2.00 & 1.74 & 1.49 \\
\hline Sodium butyrate ${ }^{3}$ & 0.00 & 0.00 & 0.00 & 0.26 & 0.51 \\
\hline Energy $\left(\mathrm{cal} \cdot \mathrm{kg}^{-1}\right)$ & 4329 & 4329 & 4329 & 4329 & 4329 \\
\hline Crude protein & 44.93 & 44.93 & 44.93 & 45.49 & 44.85 \\
\hline Fat & 9.83 & 9.83 & 9.83 & 9.77 & 9.33 \\
\hline Carbohydrate & 24.02 & 24.02 & 24.02 & 21.49 & 24.83 \\
\hline Ashes & 11.28 & 11.28 & 11.28 & 11.10 & 11.52 \\
\hline Moisture & 9.94 & 9.94 & 9.94 & 12.15 & 9.47 \\
\hline
\end{tabular}

${ }^{1}$ Micromineral premix composition: Phosphorus 7,38 $\mathrm{g} \mathrm{kg}^{-1}$; Copper $3500 \mathrm{mg} \mathrm{kg}{ }^{-1}$; Iodine $160 \mathrm{mg} \mathrm{kg}^{-1}$; Iron $20000 \mathrm{mg} \mathrm{kg}{ }^{-1}$; $\mathrm{Manganese}$ $10000 \mathrm{mg} \mathrm{kg}^{-1}$; Zinc $24000 \mathrm{mg} \mathrm{kg}^{-1}$; Selenium $100 \mathrm{mg} \mathrm{kg}^{-1}$; Vitamin A $2400000 \mathrm{UI} \mathrm{kg}^{-1}$; Vitamin D 600000 UI kg-1; Vitamin E 30000 UI kg ${ }^{-1}$; Vitamin K $3000 \mathrm{mg} \mathrm{kg}^{-1}$; Riboflavin $4500 \mathrm{mg} \mathrm{kg}^{-1}$; Pantothenic Acid $1000 \mathrm{mg} \mathrm{kg}^{-1}$; Niacin $2000 \mathrm{mg} \mathrm{kg}{ }^{-1}$; Vitamin B12 8000 $\mathrm{mg} \mathrm{kg}^{-1}$; Choline $100000 \mathrm{mg} \mathrm{kg}^{-1}$; Folic acid $1200 \mathrm{mg} \mathrm{kg}^{-1}$; Biotin $200 \mathrm{mg} \mathrm{kg}^{-1}$; Thiamine $4000 \mathrm{mg} \mathrm{kg}^{-1}$; Vitamin B6 $3500 \mathrm{mg} \mathrm{kg}^{-1}$; Vitamin C $60000 \mathrm{mg} \mathrm{kg}{ }^{-1}$. ${ }^{2}$ Macromineral premix composition: Cálcium $70 \mathrm{~g} \mathrm{~kg}^{-1}$; Magnesium $4 \mathrm{~g} \mathrm{~kg}^{-1}$; Potassium $10,80 \mathrm{~g} \mathrm{~kg}{ }^{-1}$; Sódium $5,07 \mathrm{~g} \mathrm{~kg}^{-1}$. ${ }^{3}$ Pure sodium butyrate $99 \%$ pure.

The sodium butyrate additive was incorporated into the diet at the time of formulation and preparation. The addition of the butyrate in the experimental diets replaced Cellulose. The $M$. piperita EO was added following the methodology described by DAIKIRI et al. (2013), using the dilution ratio of $1.5 \mathrm{ml}$ of EO in $100 \mathrm{~g}$ of alcohol $99.8 \%$ per $\mathrm{kg}$ of feed, applied with a manual spray over the diet, and after the inclusions, the feeds were dried at room temperature $\left(25-30{ }^{\circ} \mathrm{C}\right)$ for $24 \mathrm{~h}$ and then stored at $-18^{\circ} \mathrm{C}$ until subsequent use. It was modified by using alcohol PA 99.8\% instead of grain alcohol.

\section{Performance analysis}

After the experimental period, the live larvae were quantified, measured, and weighed. The following production parameters were evaluated: final mean length, final mean weight, final biomass (FB) $(\mathrm{FB}=$ mean final weight $\times$ number of survivors $)$, and survival rate $(\mathrm{S})[\mathrm{S}=($ Final population $\times 100) /$ Initial population].

\section{Evaluation of resistance to an infestation challenge with I. multifiliis}

At the end of the experimental period (30 days), 10 fish from each EU were transferred to circular net-cage tanks of $20 \mathrm{~cm}$ in diameter (10
L) and stored in a single fiber tank $(1,000 \mathrm{~L})$ in an external environment that was experimentally infested with I. multifiliis. The infestation was performed using cohabitation method, for four days, with juveniles of grass carp Ctenopharyngodon idella (n = 40) parasitized with I. multifiliis. The infested fish (grass carp) were kept out of the net-cage tanks, following the modified methodology described by ABDEL-HAFEZ et al. (2014b). The grass carp juveniles were obtained from local fish farming and were already infested with $I$. multifiliis. The fish were observed daily until the clinical signs of infestation (white patches) appeared. Once the pathology was confirmed, white spots presence, which occurred on the 4-day, a scraping from all fish was performed to remove and count the trophonts.

The trophonts were scraped from the body surface with a cover slip and transferred to $70 \%$ alcohol, with a standard volume $(30 \mathrm{~mL})$ for all collections. For counting, a $1 \mathrm{~mL}$ aliquot of the solution was removed after homogenization of the sample and the trophonts were quantified from direct counting using a Sedgewick-Rafter chamber under an optical microscope Zeiss Axio Vert.A1 (Zeiss, Baden-Württemberg, Germany). This process was performed three times per sample. The prevalence rate was calculated (number of infected fish/number 
of fish analyzed $\times 100)$, and the mean infestation intensity (number of trophonts in the sample/number of fish infested by trophonts) were recorded.

\section{Histological analyses}

The initial portion of the intestine (three fish per EU) was sampled and processed in paraffin following routine techniques for $3 \mu \mathrm{m}$ thick crosssections using a Leica RM 2245 manual microtome; and subsequently, stained with hematoxylin-eosin. The images were captured using a Zeiss AxioVert. A1 light microscope with a coupled camera (Axiocam ERc5s) and analyzed with the aid of the Zen Lite 2012 image analysis software program. The gut analyses consisted of determining the villi quantity, its size (length, width, and perimeter), and the amount of goblet cells contained in the intestinal mucosa villi.

\section{Statistical analysis}

To compare the means among treatments, the normality of the data was analyzed using the Shapiro-Wilks test and the homoscedasticity of the variance using the Levene test. Once the difference among the treatments (analysis of variance) was reported, the averages were compared by Tukey's test, at 5\% probability, using the Statistica ${ }^{\circledR}$ software program, version 7.0.

\section{RESULTS AND DISCUSSION}

\section{Reaction to infestation by the parasite I. multifiliis}

There was no mortality during tests to challenge infestation by parasite I. multifiliis, regardless of treatment. Dietary supplementation with $M$. piperita EO (1\% or $2 \%)$ or with sodium butyrate $(0.25 \%$ or $0.50 \%)$ did not inhibit $I$. multifiliis infestation in fish integument. The mean intensity of trophonts in the mucus of $R$. quelen larvae was similar among all diets used $(\mathrm{P}>0.05)$, i.e., control: $429.0 \pm 40.0$; EO1\%: $442.3 \pm 47.0 ; \mathrm{EO} 2 \%: 410.0 \pm$ 68.0; SB0.25\%: $434.0 \pm 61.0$; and SB0.50\%: $390.3 \pm$ 85.0 , with $100 \%$ prevalence in all treatments.

Sodium butyrate is known to exert influence on relevant health cellular functions, such as the inhibition of inflammation, thus reinforcing various defense components and reducing oxidative stress (HAMER et al., 2008). Nevertheless, jundiá larvae were not more resistant to I. multifiliis infestation even when fed a diet supplemented with up to $0.50 \%$ sodium butyrate, maintaining the same mean intensity of infestation and prevalence of fish as that from control treatment.
Diets supplemented with $M$. piperita have caused other effects on fish in previous studies. Increased bactericidal activity of skin mucus for Caspian white fish (Rutilus frisii kutum) (ADEL et al., 2015), and also increased globulin levels for Cyprinus carpio (ABASALI \& MOHAMAD, 2010), as well as developed a primary factor recognized to maintain a healthy immune system and immune functions of the blood for Oncorhynchus mykiss (NYA \& AUSTIN, 2009). However, the supplementation up to $2 \% M$. piperita EO diet was not an effective barrier for $R$. quelen larvae against infestation by $I$. multifiliis. Severe infestations were observed in all treatments, which are characterized by the presence of more than 100 trophonts per fish (XU et al., 2009).

\section{Zootechnical performance}

The larvae supplemented with the SB0.50\% diet presented better performance in all zootechnical parameters analyzed $(\mathrm{P}<0.05)$ compared to the other treatments (Table 2), except for SB0.25\%, for final length and survival. Fish supplemented with the SB0.50\% treatment had a mean final weight and survival of approximately $54 \%$ and $70 \%$ higher than control fish, respectively.

The improved performance in the zootechnical parameters in fish supplemented with sodium butyrate diet was also observed in other species, e.g., increased growth of sea bream Sparus aurata with dietary supplementation of $0.3 \%$ commercial sodium butyrate (ROBLES et al., 2013), and improvement in weight gain and feed conversion of Nile tilapia O. niloticus, and common carp Cyprinus carpio, fed with diet supplemented with sodium butyrate between $0.5 \%$ and $1.5 \%$ (ZHENG, 2009). This performance improvement of larvae has been attributed to the action of butyrate in increasing the availability of essential amino acids and nucleotide derivatives, as well as increasing transmethylation activity, conditions that aid in the synthesis of some amino acids (ROBLES et al., 2013).

In the present study, up to $2 \%$ supplementation with $M$. piperita EO promoted only a slight improvement in the evaluated parameters, but these were not significant $(\mathrm{P}>0.05)$. The $M$. piperita used as a food supplement in other studies promoted zootechnical performance improvements of some fish species. Supplementation with 3\% M. piperita in Rutilus frisii kutum juveniles promoted higher values for weight gain and feed conversion (ADEL et al., 2015). Similarly, Lates calcarifer juveniles fed for 30 days with dietary supplementation of $2 \%$ to $5 \%$ M. piperita showed 
Table 2 - Zootechnical performance of Rhamdia quelen larvae (mean \pm SD) fed for 30 days with different diets.

\begin{tabular}{lcccc}
\hline Diets & Final Average Length $(\mathrm{cm})$ & Final Weight Average $(\mathrm{g})$ & Final Biomass $(\mathrm{g})$ & Survival $(\%)$ \\
\hline Control & $3.65 \pm 0.06^{\mathrm{b}}$ & $0.52 \pm 0.05^{\mathrm{c}}$ & $14.81 \pm 1.50^{\mathrm{b}}$ & $47.77 \pm 4.15^{\mathrm{c}}$ \\
EO1\% & $3.58 \pm 0.10^{\mathrm{b}}$ & $0.49 \pm 0.02^{\mathrm{c}}$ & $18.16 \pm 1.66^{\mathrm{b}}$ & $62.22 \pm 5.66^{\mathrm{bc}}$ \\
EO2\% & $3.69 \pm 0.14^{\mathrm{b}}$ & $0.52 \pm 0.01^{\mathrm{c}}$ & $17.81 \pm 3.04^{\mathrm{b}}$ & $56.66 \pm 5.44^{\mathrm{c}}$ \\
SB0.25\% & $3.93 \pm 0.11^{\mathrm{ab}}$ & $0.67 \pm 0.03^{\mathrm{b}}$ & $30.83 \pm 0.74^{\mathrm{a}}$ & $76.66 \pm 2.72^{\mathrm{ab}}$ \\
SB0.50\% & $4.23 \pm 0.15^{\mathrm{a}}$ & $0.80 \pm 0.05^{\mathrm{a}}$ & $38.91 \pm 4.20^{\mathrm{a}}$ & $81.11 \pm 4.15^{\mathrm{a}}$ \\
\hline
\end{tabular}

Control = only diet; EO1\% = diet supplemented with 1\% Mentha piperita essential oil; EO2\%= diet supplemented with $2 \%$ M. piperita essential oil; SB $0.25 \%=$ diet supplemented with $0.25 \%$ sodium butyrate; SB $0.50 \%=$ diet supplemented with $0.50 \%$ sodium butyrate. *Overlapped values with different letters in the same column are statistically different according to Tukey's test ( $\mathrm{p}<0.05$ ).

better growth, weight gain, and feed conversion (TALPUR, 2014). It is possible that $R$. quelen larvae require higher doses of dietary supplements with $M$. piperita $\mathrm{EO}$ to improve performance.

\section{Intestinal mucosa}

Fish intestines from all treatments were intact and without detachment, lymphoeosinophilic infiltrates, or necrosis. The larvae from SB0.50\% treatment had a greater villi width than that from other treatments $(\mathrm{P}<0.05)$ and a larger amount of goblet cells than the larvae from control or supplemented with EO (Table 3). Comparing the morphology of the intestinal tissue larvae from control treatment, larvae from $\mathrm{SB} 0.50 \%$ treatment had a higher villi width and amount of goblet cells by approximately $50 \%$. However, there was not difference in the villi number in the intestinal mucosa of larvae receiving different diets $(\mathrm{P}>0.05)$.

Changes in intestinal morphology are important and may affect growth rates (TIAN et al., 2017). In the present study, the treatment with higher zootechnical performance (SB0.50\%) was the same that showed a significant increase in villi width and in quantity of goblet cells from intestinal mucosa. The intestinal mucosa of carp juveniles (C. carpio) supplemented with $1.5 \%$ or $3.0 \%$ sodium butyrate also changed, increasing villus height (LIU et al., 2014). This improvement in intestinal condition was attributed to the ability of sodium butyrate to provide energy for epithelial growth (LIU et al., 2014). This is mainly because it is a fat-soluble substance and can be rapidly absorbed and used by enteric epithelial cells (ROEDIGER, 1980). This supply of extra energy to these cells is further amplified by the decrease in the oxidation of glucose and amino acids, using butyrate as fuel (ROBLES, et al., 2013).

\section{CONCLUSION}

Although, the infestation of $R$. quelen larvae by $I$. multifiliis was not affected by $M$. piperita EO or sodium butyrate, the dietary supplementation

Table 3 - Histomorphology of the intestine of the jundiá Rhamdia quelen larvae fed with different diets.

\begin{tabular}{|c|c|c|c|c|c|}
\hline & Control & $\mathrm{EO} 1 \%$ & $\mathrm{EO} 2 \%$ & SB0.25\% & SB0.50\% \\
\hline Number of villi & $14.0 \pm 2.4^{\mathrm{a}}$ & $9.7 \pm 0.5^{\mathrm{a}}$ & $11.7 \pm 0.5^{\mathrm{a}}$ & $12.3 \pm 0.6^{\mathrm{a}}$ & $11.7 \pm 4.1^{\mathrm{a}}$ \\
\hline Length of villi $(\mu \mathrm{m})$ & $161.5 \pm 5.6^{\mathrm{ab}}$ & $127.4 \pm 16.0^{\mathrm{b}}$ & $179.7 \pm 19.8^{\mathrm{ab}}$ & $205.2 \pm 14.7^{\mathrm{a}}$ & $175.3 \pm 31.5^{\mathrm{ab}}$ \\
\hline Width of villi $(\mu \mathrm{m})$ & $58.4 \pm 5.7^{b}$ & $57.0 \pm 3.2^{\mathrm{b}}$ & $61.7 \pm 4.4^{\mathrm{b}}$ & $69.5 \pm 3.7^{\mathrm{b}}$ & $89.2 \pm 6.2^{\mathrm{a}}$ \\
\hline Goblet cell number & $9.7 \pm 0.5^{\mathrm{c}}$ & $9.3 \pm 0.9^{c}$ & $10.7 \pm 0.9^{\mathrm{bc}}$ & $12.3 \pm 0.3^{\mathrm{ab}}$ & $14.3 \pm 0.6^{\mathrm{a}}$ \\
\hline Perimeter of villi $\left(\mu \mathrm{m}^{2}\right)$ & $5,541.0 \pm 463.7^{\mathrm{ab}}$ & $3,030.0 \pm 50.3^{b}$ & $5,184.6 \pm 1,437.0^{\mathrm{ab}}$ & $6,653.5 \pm 809.9^{\mathrm{a}}$ & $5,133.0 \pm 1,662.0^{\mathrm{ab}}$ \\
\hline
\end{tabular}

Control = only diet; EO1\% = diet supplemented with 1\% Mentha piperita essential oil; EO2\%= diet supplemented with $2 \%$ M. piperita essential oil; SB $0.25 \%=$ diet supplemented with $0.25 \%$ sodium butyrate; SB $0.50 \%=$ diet supplemented with $0.50 \%$ sodium butyrate.

"Overlapped values with different letters in the same line are statistically different according to Tukey's test $(\mathrm{P}<0.05)$. 
with $0.50 \%$ sodium butyrate improved the intestinal condition and zootechnical performance of the fish.

\section{ACKNOWLEDGMENTS}

The authors would like to thank the Laboratory of Medicinal Plants and Phytochemistry of Embrapa Amazônia ocidental for the supply of the essential oil of Mentha piperita; the Nucleus of Studies in Aquaculture Pathology of the Universidade Federal de Santa Catarina (UFSC) for concession of the necessary infrastructure for the histological analyzes; the Conselho Nacional de Desenvolvimento Científico e Tecnológico (CNPq) for the productivity research fellowship granted for EZF (Grant 304949/2017-5); Dr. José Luíz Pedreira Mouriño for help in the study planning and colaboration; Dr. Gabriel Fernandes Alves Jesus for support in formulation and diets preparation; and was financed in part by the Coordenação de Aperfeiçoamento de Pessoal de Nível Superior (CAPES), Brasil - Finance code 001.

\section{BIOETHICS AND BIOSSECURITY COMMITTEE APPROVAL}

Procedure approved by the Committee on Ethics in the Use of Animals at Universidade Federal de Santa Catarina, protocol No. 3451200917.

\section{DECLARATION OF CONFLICT OF INTERESTS}

The authors declare no conflict of interest. The funding sponsors had no role in the design of the study; in the collection, analyses, or interpretation of data; in the writing of the manuscript, and in the decision to publish the results.

\section{AUTHORS' CONTRIBUTIONS}

All authors contributed equally for the conception and writing of the manuscript. All authors critically revised the manuscript and approved of the final version.

\section{REFERENCES}

ABDEL-HAFEZ, G, et al. Possibilities to control Ichthyophthirius multifiliis infestation with medicated feed in rainbow trout (Oncorhynchus mykiss) and chub (Leuciscus cephalus). Parasitology Research, v.113, n.3, p.1119-1126, 2014b. Available from: <http://dx.doi.org/10.1007/s00436-013-3749-9>. Accessed: Oct. 11, 2018. doi: 10.1007/s00436-013-3749-9.

ABASALI, H.; MOHAMAD, S. Immune response of common carp (Cyprinus carpio) fed with herbal immunostimulants diets. Journal of Animal and Veterinary Advances, v.9, n.13, p.1839-1847, 2010. Available from: <http://dx.doi.org/10.3923/javaa.2010.1839.1847>. Accessed: Jul. 11, 2018. doi: 10.3923/javaa.2010.1839.1847.

ADEL, M, et al. Effects of dietary peppermint (Mentha piperita) on growth performance, chemical body composition and hematological and immune parameters of fry Caspian white fish (Rutilus frisii kutum). Fish \& Shellfish Immunology, v.45, n.2, p.841-847, 2015. Available from: <http://dx.doi.org/10.1016/j.fsi.2015.06.010>. Accessed: Jul. 11, 2018. doi: 10.1016/j.fsi.2015.06.010.
AHMED, H. A.; SADEK, K. M. Impact of dietary supplementation of sodium butyrate and/or protexin on the growth performance, some blood parameters, and immune response of Oreochromis niloticus. International Journal of Agriculture Innovations and Research, v.3, p.985- 991, 2015.

ANVISA. Agência Nacional de Vigilância Sanitária, RDC N ${ }^{\circ}$ 360 , de 23 de dezembro de 2003. Available from: <https://www. gov.br/agricultura/pt-br/assuntos/inspecao/produtos-vegetal/ legislacao-1/biblioteca-de-normas-vinhos-e-bebidas/resolucaordc-no-360-de-23-de-dezembro-de-2003.pdf/view>. Accessed: May, 26, 2018.

ASSOCIATION OF OFFICIAL ANALYTICAL CHEMISTS (AOAC). Official Methods of Analysis, 17th ed. AOAC, Gaithersburg, MD, 1999.

BALDISSEROTTO, B. Freshwater fish culture in Rio Grande do Sul State: actual situation, problems and future perspectives. Ciência Rural, v.39, n.1, p.291-299, 2009. Available from: $<$ http:// dx.doi.org/10.1590/S0103-84782008005000046>. Accessed: Sep. 23, 2018. doi: 10.1590/S0103-84782008005000046.

BEDFORD, A.; GONG, J. Implications of butyrate and its derivatives for gut health and animal production. Animal Nutrition, 2017. Available from: <https://reader.elsevier.com/ reader/sd/pii/S2405654517301397?token=EC2F1ECD1B372AE3 A0008E067F9D739D750599CC6D53A810878377EA0A4E2EA 0E1C9C7BB11B7D0A2A7296CF4BF03D3AC >. Accessed: May, 26, 2020. doi: 10.1016/j.aninu.2017.08.010.

DAIKIRI, J. K, et al. Procedimento para inclusão de óleos essenciais em rações para peixes. Circular Técnica 42. Embrapa - AM, 8p. 2013. Available from: <https://ainfo.cnptia. embrapa.br/digital/bitstream/item/100643/1/Circ-Tec-42.pdf $>$. Accessed: Nov. 21, 2017.

FRACALOSSI, D. M, et al., Performance of Jundiá, Rhamdia quelen, and Dourado, Salminus brasiliensis, in earth ponds of southern Brazil. Acta Scientiarum Animal Sciences, v.26, p.345-352, 2004. Available from: <http://periodicos.uem. br/ojs/index.php/ActaSciAnimSci/article/view/1806/1179>. Accessed: Jun. 22, 2020.

GUILloteaU, P, et al. From the gut to the peripheral tissues: the multiple effects of butyrate. Nutrition Research Reviews, v.23, n.2, p.366-384, 2010. Available from: $<$ https://doi-org.ez9.periodicos.capes.gov. br/10.1017/S0954422410000247>. Accessed: Jan. 10, 2019. doi: $10.1017 / \mathrm{S} 0954422410000247$.

HAMER, H. M, et al. Review article: the role of butyrate on colonic function. Alimentary Pharmacology \& Therapeutics, v.27, n.2, p.104-119, 2008. Available from: <https://doi.org/10.1 111/j.1365-2036.2007.03562.x>. Accessed: Dec. 16, 2018. doi: 10.1111/j.1365-2036.2007.03562.x.

HASHIMOTO, G. S. O, et al. Essential oils of Lippia sidoides and Mentha piperita against monogenean parasites and their influence on the hematology of Nile tilapia. Aquaculture, v.450, p.182-186, 2016. Available from: <http://dx.doi.org/10.1016/j. aquaculture.2015.07.029>. Accessed: Dec. 14, 2018. doi: 10.1016/j.aquaculture.2015.07.029.

$\mathrm{KOH}, \mathrm{C} . \mathrm{B}$, et al. Effects of a dietary organic acids blend and oxytetracycline on the growth, nutrient utilization and total 
cultivable gut microbiota of the red hybrid tilapia, Oreochromis sp., and resistance to Streptococcus agalactiae. Aquaculture Research, v.47, p.357-369, 2016. Available from: <https:// onlinelibrary.wiley.com/doi/epdf/10.1111/are.12492>. Accessed: Jun. 22, 2020. doi: 10.1111/are.12492.

LIU, M, et al. Dietary supplementation of sodium butyrate may benefit growth performance and intestinal function in juvenile grass carp (Ctenopharyngodon idellus). Aquaculture Research p.1-10, 2016. Available from: <https://www.onlinelibrary.wiley. com/doi/10.1111/are.13230>. Accessed: Jun. 22, 2020. doi: doi:10.1111/are.13230

LIU, W, et al. Effects of dietary microencapsulated sodium butyrate on growth, intestinal mucosal morphology, immune response and adhesive bacteria in juvenile common carp (Cyprinus carpio) pre-fed with or without oxidised oil. British Journal of Nutrition, v.112, n.1, p.15-29, 2014. Available from: $<$ https://doiorg.ez9.periodicos.capes.gov.br/10.1017/S0007114514000610>. Accessed: Jan. 13, 2019. doi: 10.1017/S0007114514000610.

LÜCKSTÄDT, C. The use of acidifiers in fish nutrition. CAB Reviews: Perspectives in Agriculture, Veterinary Science. Nutrition and Natural Resources, v.3, p.1-8, 2008. Available from: $\quad<$ http://wfish.de/fulltext/CAB_review-paper_acidifiersin-fish-nutrition.pdf $>$. Accessed: May, 27,2020 . doi: 10.1079/ PAVSNNR20083044.

MALHEIROS, D. F, et al. Toxicity of the essential oil of Mentha piperita in Arapaima gigas (Pirarucu) and antiparasitic effects on Dawestrema spp. (Monogenea). Aquaculture, v.455, p.81-86, 2016. Available from: <http://dx.doi.org/10.1016/j. aquaculture.2016.01.018>. Accessed: Dec. 14, 2018. doi: 10.1016/j.aquaculture.2016.01.018.

MORAIS, S. R, et al. Chemical constituents of essential oil from Lippia sidoides Cham. (Verbenaceae) leaves cultivated in Hidrolândia, Goiás, Brazil. International Journal of Analytical Chemistry, p.1-4, 2012. Available from: <http:// dx.doi.org/10.1155/2012/363919>. Accessed: Dec. 14, 2018. doi: $10.1155 / 2012 / 363919$

NYA, E. J.; AUSTIN, B. Use of dietary ginger, Zingiber officinale Roscoe, as an immunostimulant to control Aeromonas hydrophila infections in rainbow trout, Oncorhynchus mykiss (Walbaum). Journal of Fish Diseases, v.32, n.11, p.971-977, 2009b. Available from: $\quad<$ https://doi.org/10.1111/j.1365-2761.2009.01101.x>. Accessed: Dec. 14, 2018. doi: 10.1111/j.1365-2761.2009.01101.x.

POTZERNHEIM, M. C. L, et al. Chemical characterization of essential oil constituents of four populations of Piper aduncum L. from Distrito Federal, Brazil. Biochemical Systematics and Ecology, v.42, p.25-31, 2012. Available from: $<$ https://doi. org/10.1016/j.bse.2011.12.025>. Accessed: Dec. 12, 2018. doi: 10.1016/j.bse.2011.12.025

ROBLES, R, et al. Effect of partially protected butyrate used as feed additive on growth and intestinal metabolism in sea bream (Sparus aurata). Fish Physiology and Biochemistry, v.39, n.6, p.1567-1580, 2013. Available from: <https://doi.org/10.1007/ s10695-013-9809-3>. Accessed: Dec. 12, 2018. doi: 10.1007/ s10695-013-9809-3.

ROEDIGER, W. E. The colonic epithelium in ulcerative colitis: an energy-deficiency disease? The Lancet, v.316, n.8197, p.712-715, 1980. Available from: <https://doi.org/10.1016/S01406736(80)91934-0>. Accessed: Dec. 12, 2018. doi: 10.1016/S01406736(80)91934-0.

SUN, L, et al. Effects of sodium butyrate on growth and intestinal cell proliferation of Carassius auratus. Journal of Fishery Sciences of China, v.20, p.893-901, 2013. Available from: <http://www. aquaticjournal.com/article/doi/10.3724/SP.J.1118.2013.00893>. Accessed: Mar. 22, 2020. doi: 10.3724/SP.J.1118.2013.00893.

TALPUR, A. D. Mentha piperita (Peppermint) as feed additive enhanced growth performance, survival, immune response and disease resistance of Asian sea bass, Lates calcarifer (Bloch) against Vibrio harveyi infection. Aquaculture, v.421-421, p.71-78, 2014. Available from: <https://doi.org/10.1016/j. aquaculture.2013.10.039>. Accessed: Dec. 14, 2018.

TIAN, L, et al. Sodium butyrate improved intestinal immune function associated with NF-kB and p38MAPK signalling pathways in young grass carp (Ctenopharyngodon idella). Fish \& Shellfish Immunology, v.66, p.548-563, 2017. Available from: <http://dx.doi.org/10.1016/j.fsi.2017.05.049>. Accessed: Jan. 20, 2019

VALLADÃO, G. M. R, et al. Essential oils to control ichthyophthiriasis in pacu, Piaractus mesopotamicus (Holmberg): special emphasis on treatment with Melaleuca alternifolia. Journal of Fish Diseases, v.39, n.10, p.1143-1152, 2016. Available from: $<$ https://doi.org/10.1111/jfd.12447>. Accessed: Oct. 11, 2018. doi: $10.1111 /$ jfd. 12447 .

XU, D. H, et al. Effect of immunization of channel catfish with inactivated trophonts on sérum and cutaneous antibody titers and survival against Ichthyophthirius multifilis. Fish \& Shellfish Immunology, v.26, n.4, p.614-618, 2009. Available from: <https:// doi.org/10.1016/j.fsi.2008.09.015>. Accessed: Oct. 11, 2018. doi: 10.1016/j.fsi.2008.09.015

ZANIBONI-FILHO, E, et al. Catálogo ilustrado de peixes do alto rio Uruguai. Florianópolis: Ed. Da UFSC, 2004, 128p.

ZANIBONI-FILHO, E.; SCHULZ, U. H. Migratory fishes of the Uruguai river. In: CAROLSFIELD, J. et al. (Eds.) Migratory fishes of the South America: biology, social importance and conservation status. Victoria: World Fisheries Trust/The World Bank/ International Development Research Centre, p.135168, 2003. Available from: <https://www.researchgate.net/ publication/312455850>. Accessed: Nov. 10, 2018.

ZHENG, R. G. The effect of sodium butyrate on the growth performance and intestinal mucous structure of fresh water fish. Master's thesis, 2009. Available from: <http://www.globethesis. com/?t=>. Accessed Mar. 15, 2018. 